\title{
The first big acquisition
}

\section{Heinrich Schliemann, Ingvald Undset and Oscar II's Gifts to the Early Ethnographical Museum in Oslo}

\author{
Axel Seeberg $(\dagger)$ \\ With contributions by J. Rasmus Brandt
}

Axel Seeberg (1931-2011) was Professor of Classical Archaeology at the University of Oslo, Norway, from 1974 until his retirement in 2001 (Fig. 1). He studied under Professor H. P. L'Orange at the same university, and took his concluding Mag. Art-exam in 1955, followed by a period as research fellow (1958-1960) and then as University Lecturer, also at Oslo. During a year-long stay at University College London in 1952/53, he met Professor T. B. L. Webster (1905-1974), who inspired and encouraged him to devote his research to various aspects of the ancient theatre. This work resulted in two major publications: Corinthian Komos Vases (Bulletin of the Institute of Classical Studies, supplement 27, London: 1971), and, co-authored with J. R. Green, Sydney University, Monuments Illustrating New Comedy. Third edition revised and enlarged (Bulletin of the Classical Institute, supplement 50, 2 vols., London: 1995). The last work was described by one reviewer as 'Herculean'.

Seeberg was fascinated by, and cared deeply about, the Greek and Roman antiquities in public and private collections in Norway; many objects he published himself, others he encouraged his students to publish. In 1972/73

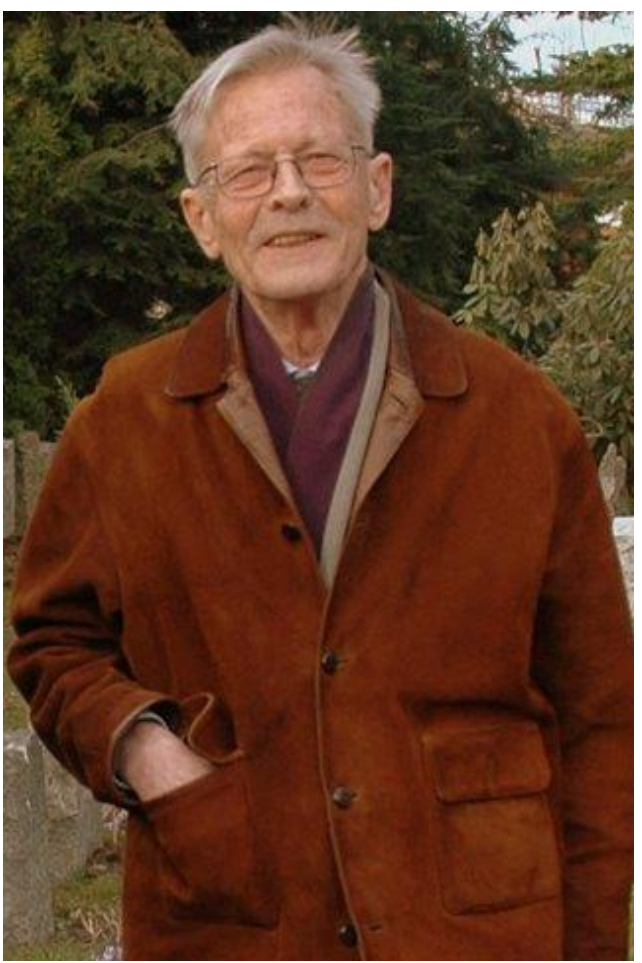

Fig. 1 Axel Seeberg (†)

Photo: Private (courtesy of the Seeberg family) he was a visiting scholar at the Institute for Advanced Study, Princeton University, USA, and in 1982 be was elected a member of the Norwegian Academy of Sciences. 
Abstract. In 1887 King Oscar II of Sweden and Norway donated 18 ancient objects 'that had been given to him by Schliemann' to the then Ethnographical Museum (now the Museum of Cultural History, University of Oslo). In this, his very last article, the late Axel Seeberg wrote about these objects and discussed the descriptions and the provenances given to them in the first museum inventory list. Many of the objects have already been published (some of them in CVA Norway 1), but not all. Here, the donation is presented in full for the first time. Some of the vases may have been acquired (not excavated) by Heinrich Schliemann in the years 1880/81, during his archaeological activities at Orchomenos. Others may have been bought in the Athenian art market. To the list is added a Tanagra figurine bought by the Norwegian archaeologist, Ingvald Undset, in Athens in 1883, when he travelled around Greece and visited the town where Heinrich Schliemann was staying.

An interesting gift was received by the museum in 1887 from King Oscar II (1829-1907),', when be donated 18 ceramic objects that had been presented to him by Schliemann, the famous explorer of Greek Antiquity.

These are the words of Dr Yngvar Nielsen (1877-1916) in his account of the first fifty years in the history of what was then the Ethnographical Museum of the University of Oslo, now part of the Museum of Cultural History. He went on:

King Oscar II thus demonstrated his good will and interest in the museum, followed in time by many similar gestures. Not only did he personally contribute valuable gifts, his good will aided the museum indirectly also: royal protection generated a popular favour resulting in many of its more valuable acquisitions. Future ethnographical studies in this country will always remain deeply in his debt. ${ }^{2}$

Amen! The name 'King Oscar' means far, far more to the nation than a brand of sardines; ${ }^{3}$ and one recalls that his collection of old buildings at a site on the royal manor farm, Bygdøy, became the nucleus of Norsk Folkemuseum, one of the very first in a more than nationwide wave of open-air museums of cultural history. ${ }^{4}$ It was early days, but in the first years under the directorship of that eminent historian, Professor P. A. Munch (1857-1861), the museum had already received a few Mediterranean antiquities; he never catalogued them, as he hoped to use them to establish a new sub-section unit within the university collections (they were catalogued by his successor - alphabetically under a collective number). Nevertheless, the royal gift dramatically increased the holdings. In the list accompanying the text (see appendix), the items appear with their current inventory number, accessible through the Museum of Cultural History's digital database.

Who furnished the technical details? Not Dr Nielsen, who was a man of many skills, but not a classical archaeologist. No doubt there were Norwegians capable of recognizing Aktaion

\footnotetext{
${ }^{1}$ King Oscar II was king of the union of Sweden and Norway from 1872 to the dissolution of the union in 1905; after that he was only king of Sweden.

The editors express their gratitude to Adam Lindhagen, who has digitized the text, and to Kristin Bornholdt Collins, who has proofread it.

${ }^{2}$ Nielsen 1972, 72. Translation by Axel Seeberg.

3 'King Oscar sardines' was established by the Stavanger Canning Company in 1873. The corporation became world renowned for canned seafood, and in 1902 King Oscar II of Norway and Sweden supplied the company with a royal concession to apply his name and image on the crates.

${ }^{4}$ See Eriksen 2009, 69ff.; Hegard 1984, $32-59$ (on King Oscar II); Zippelius 1974, 115-123.
} 


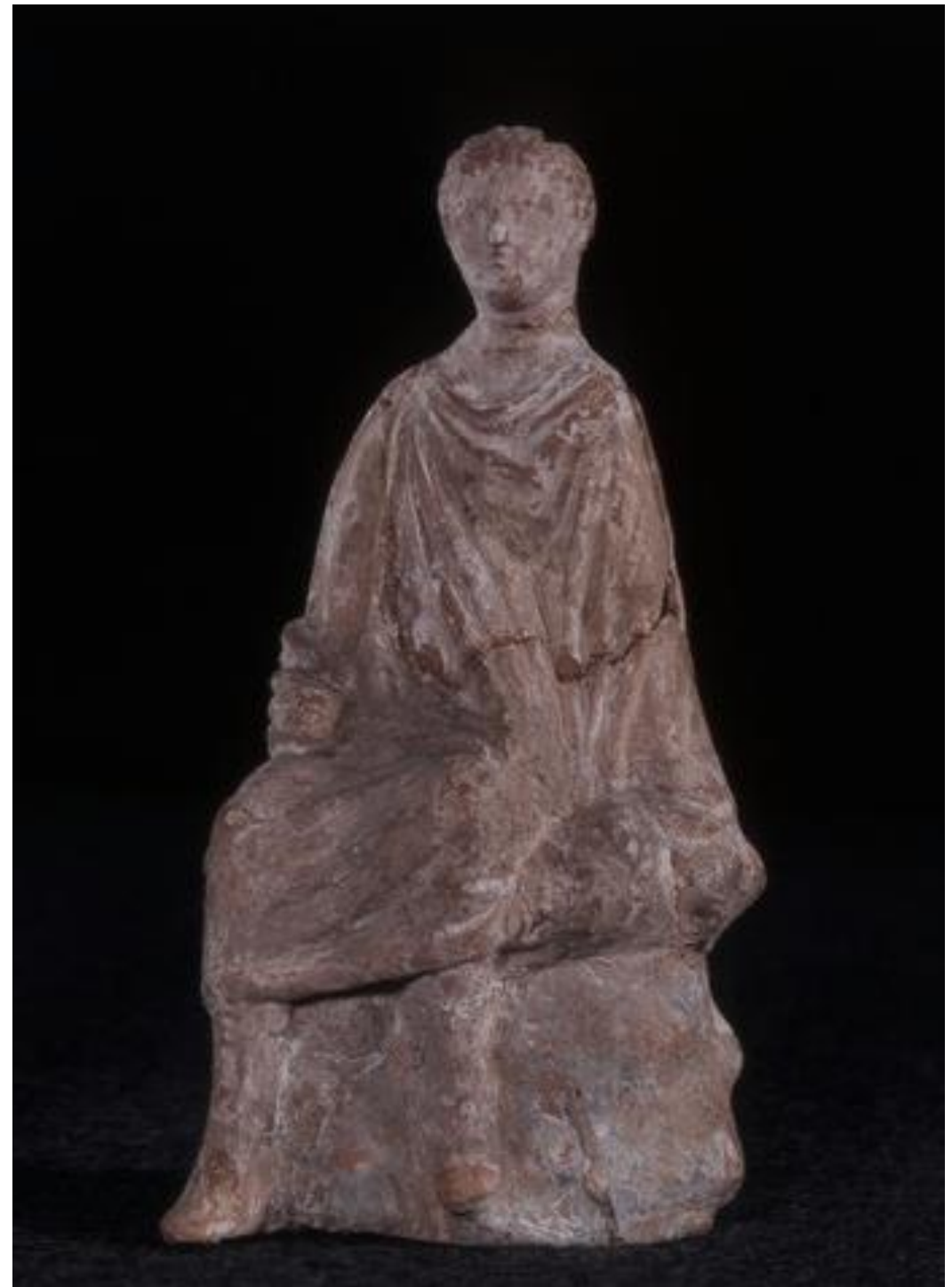

Fig. 2 Tanagra figurine. Photo: (C) Museum of Cultural History, inv. no. C41776.

and deciphering the Odyssey scene, but no more than one who also had a working knowledge of ancient pottery Ingvald M. Undset (18531893), the noted prehistorian. ${ }^{5}$ It is probably not a coincidence that the very next entry in the accessions list is 'a terracotta figure from Tanagra representing a woman in ample folded drapery, seated on a rock painted in pink colour, hair reddish-brown, bought from Dr Ingvald Undset' (Fig. 2, C41776). Even he could hardly have known the provenances of the objects. Provenance is polysemic: in contemporary Classical Archaeology the usual and recommended sense is 'the earliest attested presence in modern times' - a find-spot, or, e.g. a collection. Often, especially in the past, it has meant a supposed place of 'origin', or even a vague type designation based on a resemblance to objects of supposedly known origin. The Dipylon provenances of the list are unreliable, quite likely a dealer's tag meaning little more than 'Geometric'. The elegant little drinking-cup is Attic Geometric, as shown by the parallels cited in the second volume of the Norwegian Corpus V asorum publication (Fig. 3, C41761). ${ }^{6}$ The miniature bydria seems unlikely to have come from the Dipylon cemetery (Fig. 4, C41760). ${ }^{7}$ It could be the product of some rural Attic workshop, or of a neighbouring region such as Euboea or Boeotia. It is not easy to imagine any practical purpose for such a pot, and bydriskai are indeed rare: in the Athenian Agora excavations only a single specimen ('perhaps not Attic') had turned up by $1970 .{ }^{8}$ Copies in miniature of shapes made for dedication are common in sanctuaries; full-size bydriai were used for fetching water on sacred occasions, and might have been copied in this way.

\footnotetext{
${ }^{5}$ Ingvald M. Undset (1853-1893) was a leading Norwegian archaeologist whose international fame was achieved by his groundbreaking doctoral thesis from 1881, which was quickly translated into German: Das erste Auftreten des Eisens in Nord-Europa: eine Studie in der vergleichenden vorbistorischen Archäologie. Hamburg: O. Meissner 1882.

${ }^{6}$ CV $A$ Norway 2, 87. 254, pl. 43.

${ }^{7}$ CV A Norway 2, 87. 255, pl. 43.

${ }^{8}$ Sparkes and Talcott 1970, 334, no. 1391, pl. 45.
} 


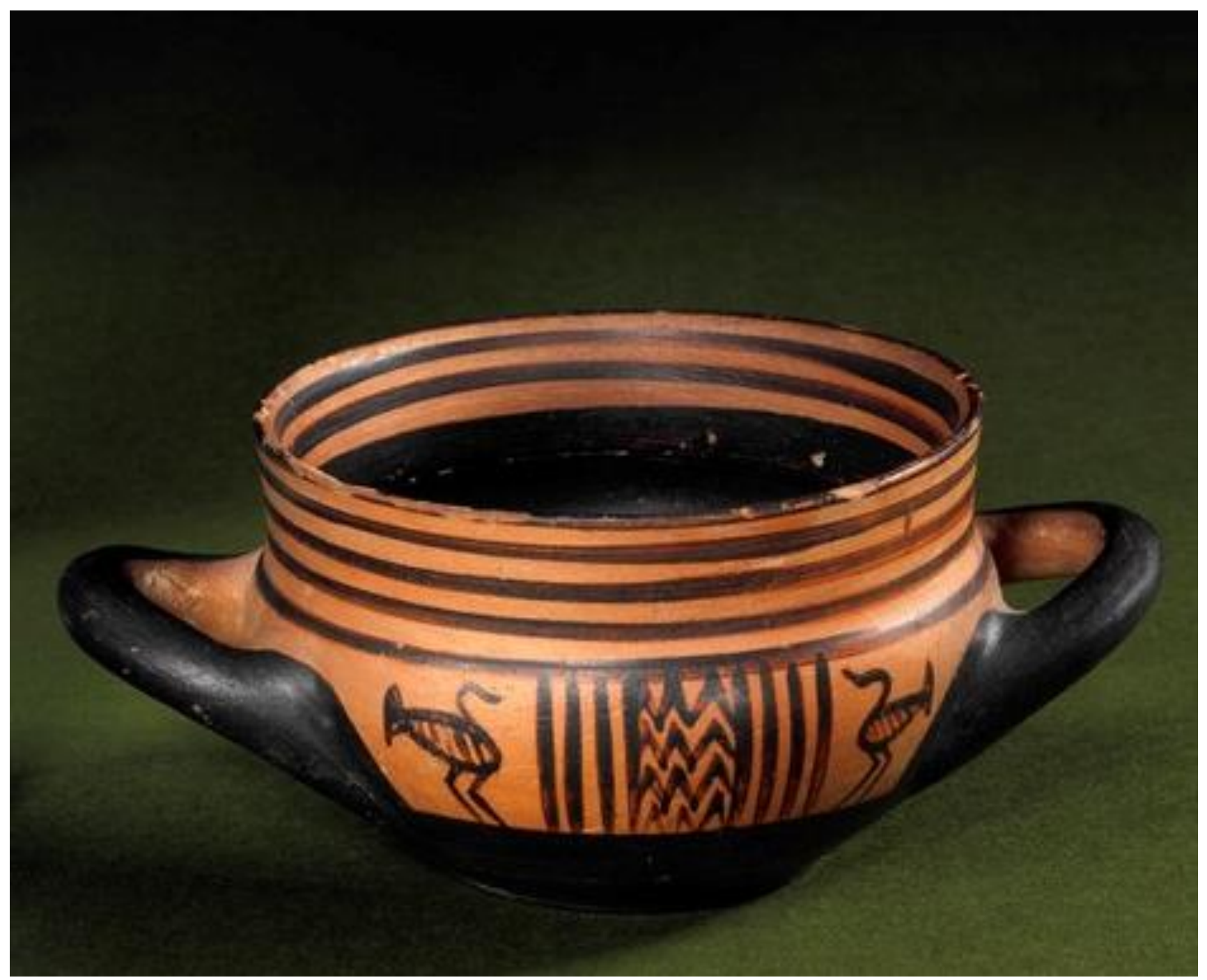

Fig. 3 Vase with two handles and open mouth. From Athens, 'pre-Homeric'. Photo: (C) Museum of Cultural History, inv. no. C41761.

One thinks of an oddity in Geometric art: miniature jugs placed on top of full-size ones, as an extra mouth. An Oslo collection, the Museum of Applied Art, has a good example. The context is dated variously in the publication, but could constitute an early Geometric tomb-group. ${ }^{9}$ Mrs A. D. Ure pointed out the resemblance in vase-paintings from Eretria in Euboea, and she was probably right. Eretria exported her wares widely, to Olbia in the North and Sicily in the West, and there are many finds from Euboea itself and from Boeotia. Her atticizing pots may have sold less well in Attica, except possibly in outlying communities near to the place of manufacture. The 'Athenian' lekythos with two sirens has features that are rare on comparable Attic vases: minimal use of incision, here for eyes and mouth only, and long curving bands of white alternating with purple (Fig. 5, C41797). ${ }^{10}$

\footnotetext{
9 CVA Norway 2, 91. 262, pl. 46. On miniatures see Kourou 2007, 62-76.

${ }^{10}$ CV A Norway 1, 25, pl. 22.3-4. On sirens, see Hofstetter 1990, a publication that does not include the Oslo lekythos.
} 


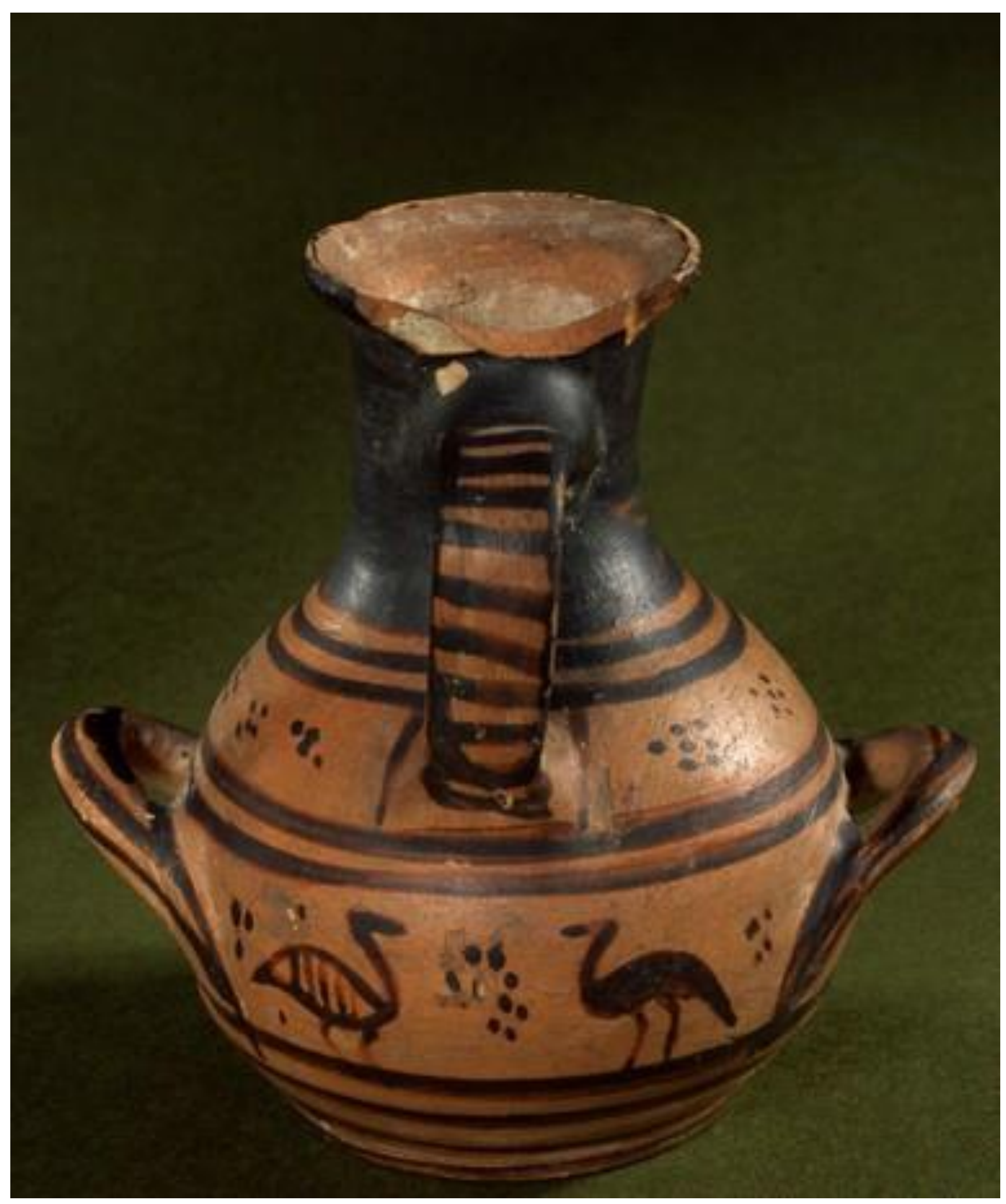

Fig. 4 Three-handled vase (miniature hydria). From Athens, 'pre-Homeric'. Photo: (C) Museum of Cultural History, University of Oslo, inv. no. C41760. 


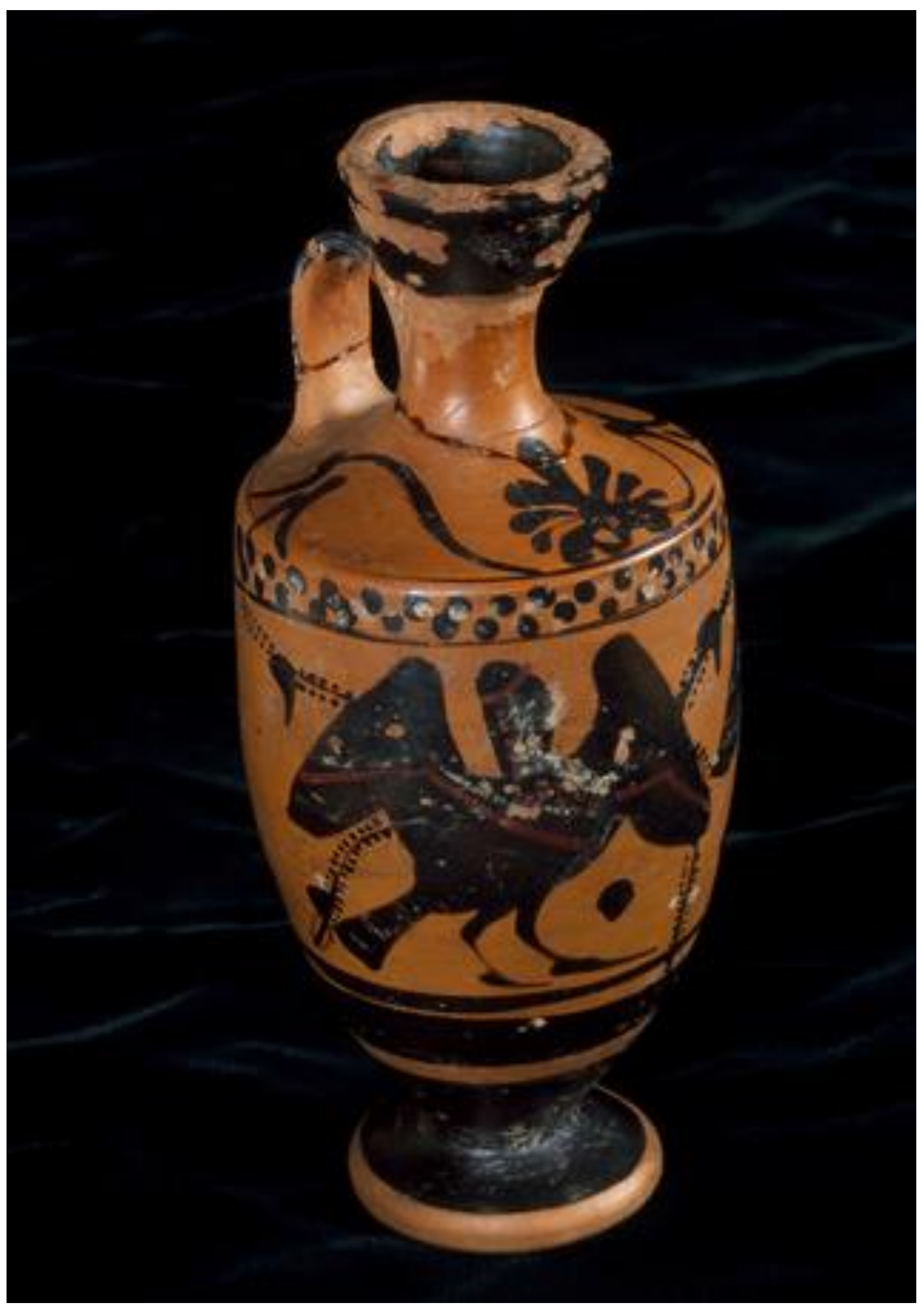

Fig. 5 'Athenian' lekythos with two black sirens. $\sigma^{\text {th }}$ century $B C$. Photo: (C) Museum of Cultural Historv, University of Oslo, inv. C41797. 

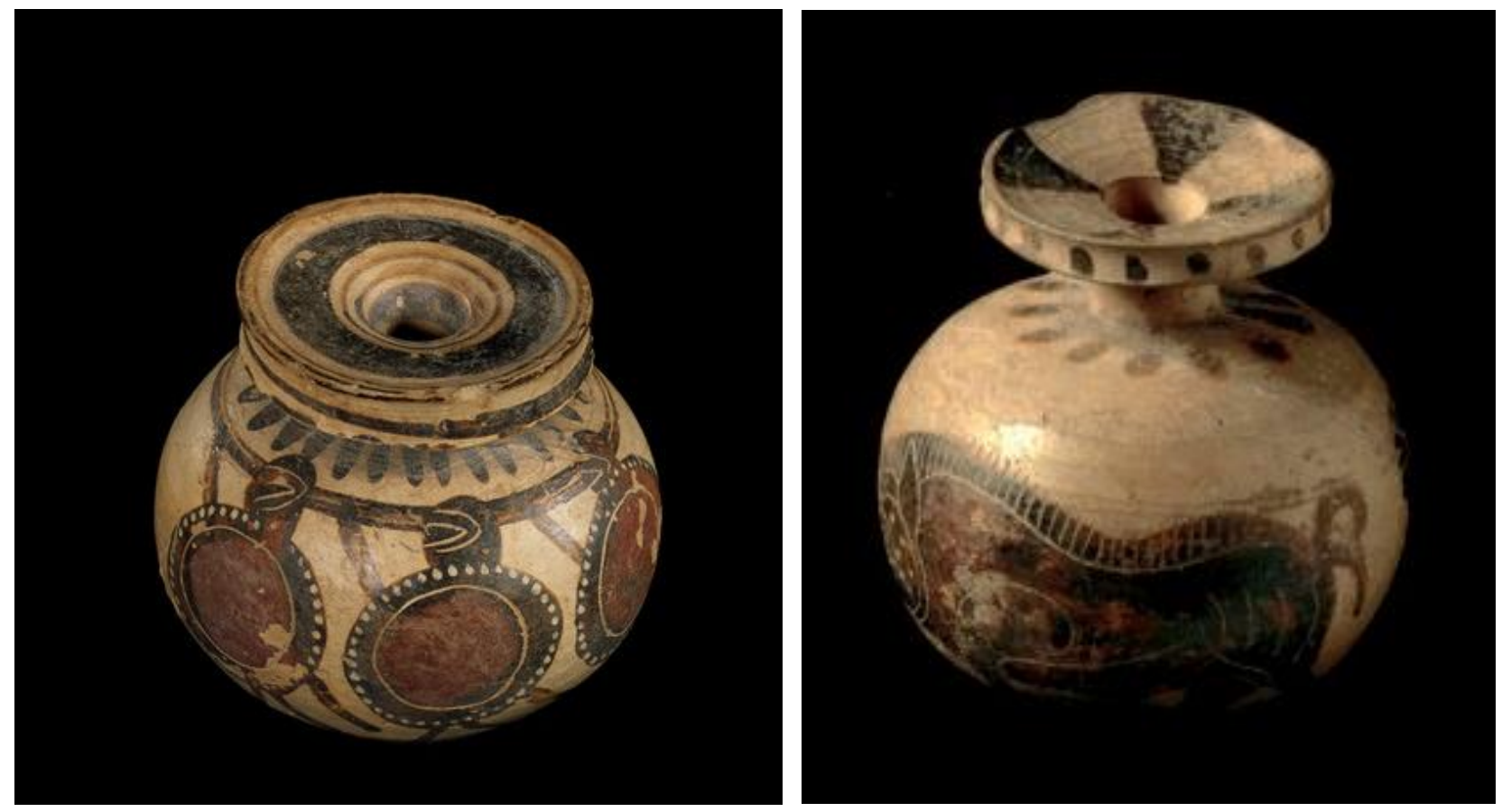

Fig. 6 Aryballos with three hoplites. From Tanagra, $\sigma^{\text {th }}$ century BC. Photo: (C) Museum of Cultural History, University of Oslo, inv. no. C41804.

Fig. 7 Aryballos with a boar. From Tanagra, $\sigma^{\text {th }}$ century BC. Photo: (C) Museum of Cultural History, University of Oslo, inv. no. C42142.

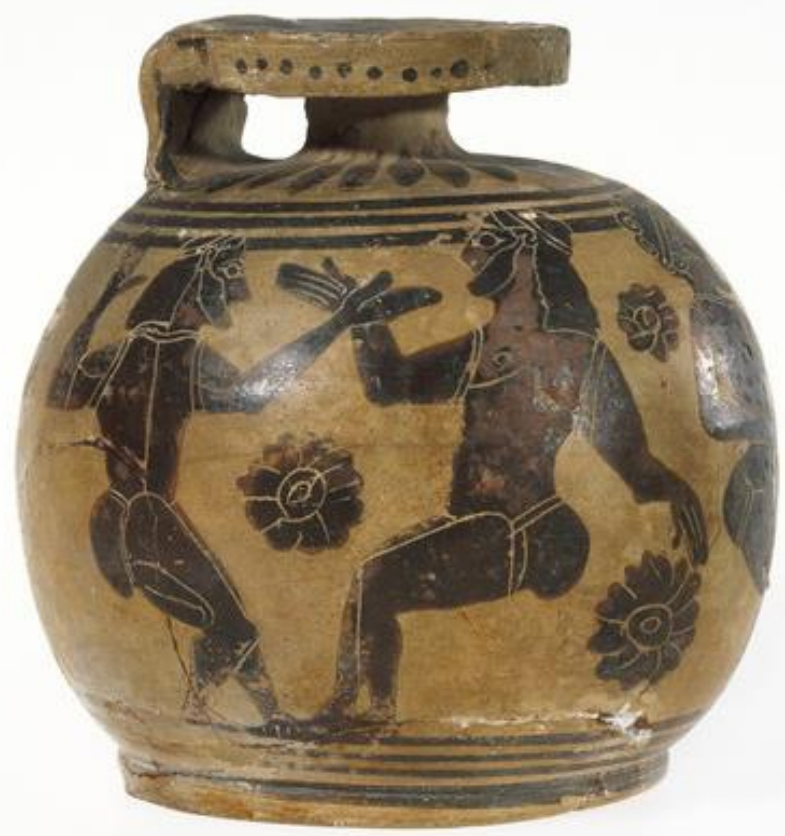

In the 1880s 'Tanagra' was probably a common dealer's provenance, but for figurines rather than early pottery; it may well be trustworthy in the case of notoriously Corinthian types - the aryballos with round-shielded warriors (Fig. 6, C41804), ${ }^{11}$ the small one with a boar (Fig. 7, C42142), ${ }^{12}$ and the flat-bottomed aryballos with komasts (Fig. 8, C41814). ${ }^{13}$ The almond-lekythos from Thebes has parallels there, and judging from the clay, pale with a red ochre surface, could be Boeotian (Fig. 9, C41789).

Fig. 8 Aryballos with five komasts. From Boeotia, $6^{\text {th }}$ century BC. Photo: (C) Museum of Cultural History, University of Oslo, inv. no. C41814.

\footnotetext{
${ }^{11}$ CV A Norway 1, 15, pl. 2.5.

${ }^{12}$ CVA Norway 1, 13-14, pl. 1.6-8; Seeberg 1953.

${ }^{13}$ CV A Norway 1, 15-16, pls 2.9 and 3.1-2; Seeberg 1971, 32, no. 159.
} 


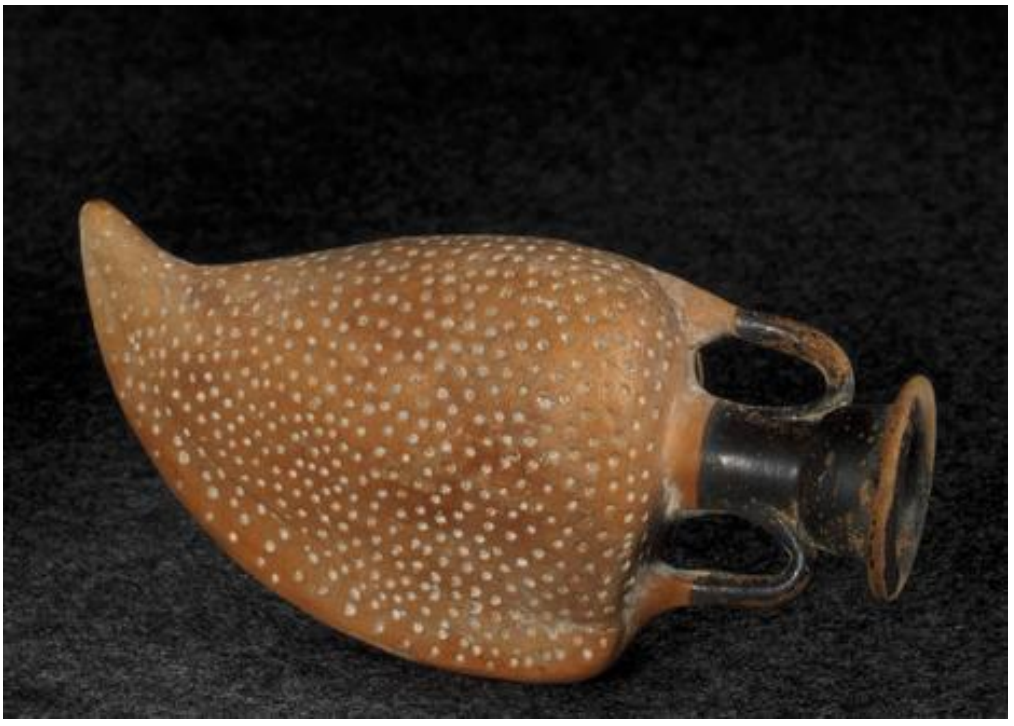

Fig. 9 Two-handled vase in the shape of an almond. From Thebes. Photo: (C) Museum of Cultural History, University of Oslo, inv. no. C41789.

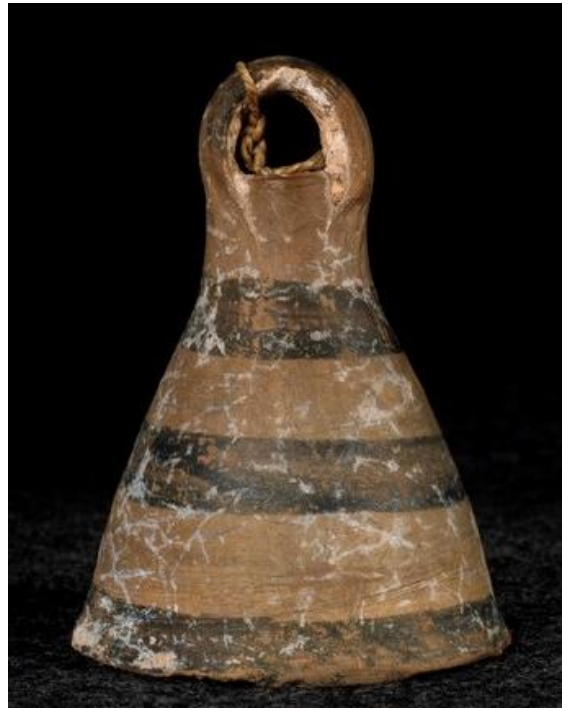

Fig. 10 Bell. From Thebes, Boeotia. Photo: (C) Museum of Cultural History, University of Oslo, inv. no. C41788.

Finally, the terracotta bell from Thebes, previously unpublished, measures $50 \mathrm{~mm}$ in width at the base and $64 \mathrm{~mm}$ in height, with a loop at the top where the clapper was suspended through a hole; three transverse dark bands are the only decoration (Fig. 10, C41788). Thebes has yielded many such objects, some from the tomb of the men of Thespiai who fell in the battle of Delion in 425 BC. What were they for? Toys or magic have been suggested, but clay bells with clay or wooden clappers could not make the kind of noise enjoyed by children, and would leave spirits unimpressed. Probably, as has also been suggested, these are cheap miniature images of metal bells for some funereal use - a usage comparable to the manufacture of miniature pots for dedication.

In his diary entry for 28 February 1887, Yngvar Nielsen noted that during a dinner at the palace, King Oscar had announced his intention of shortly presenting to the Ethnographical Museum some ancient Greek objects 'that had been given to him by Schliemann'. ${ }^{14}$ In official documents from the university the Schliemann connection is not mentioned; nor - oddly enough - is there any record, in available sources, of contact between Schliemann and King Oscar. ${ }^{15}$ A local newspaper, reporting on the gift, wrote 'The genuineness of the vases is guaranteed by an accompanying attestation by Dr Schliemann'. ${ }^{16}$ There seems to be no real reason to doubt that the vases did in fact come from Schliemann's collection, and that he provided the information about their provenance. Furthermore, in view of this information, it seems likely that some were acquired (not, of course, excavated) by him in the course of the years 1880/81, when he spent some time in Boeotia during his excavation at Orchomenos. In the published part of his correspondence, there is just one allusion to what seems to be a private store of classical antiquities on which he could draw for costly presents: a letter to Queen Sophia of the Netherlands, promising her some selected Tanagra figurines. ${ }^{17}$

\footnotetext{
14 Nielsen 1913, 133. On Schliemann's collection, see Wieseler 1874, 63-132.

15 I am indebted for much kind help to librarians and archivists in Stockholm and Oslo; in particular, Lars Wickström of the Swedish State Archive. Christian Holst, chamberlain to King Oscar and in charge of his Norwegian correspondence, allowed a release of the official letters in 1940, but ordered the destruction of private ones. The Swedish correspondence is preserved in the Bernadotte Archive, Stockholm Royal Palace.

16 Morgenbladet, 15 March 1887.

${ }_{17}^{17}$ Schliemann 1958, 36, no. 8, dated Athens, 2 March 1876. He observes that the figurines will be taken by him to Constantinople and sent from there, as the Greek authorities maintained a strict ban on unauthorized exportation of antiquities.
} 

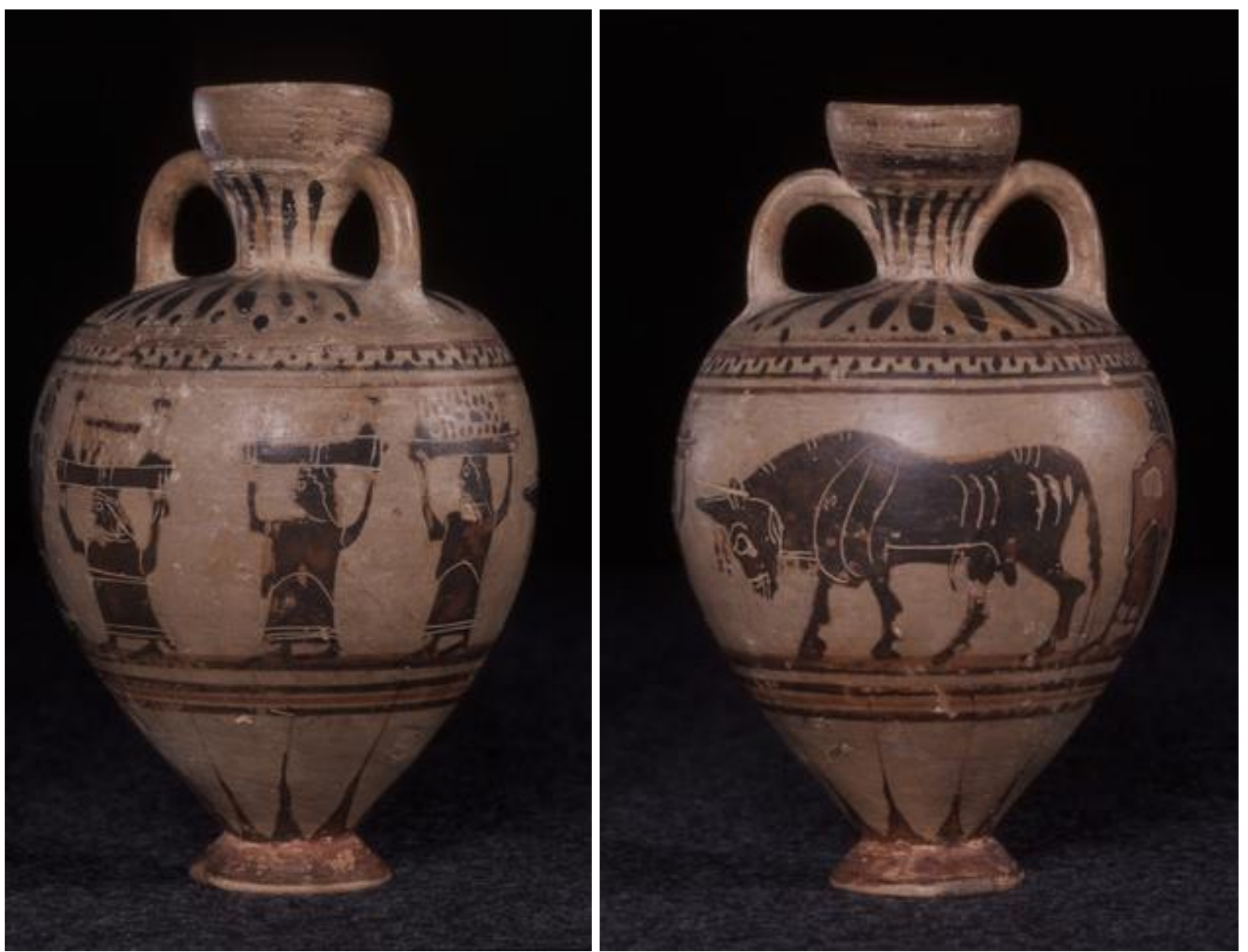

Fig. 11a-b Corinthian amphoriskos. $6^{\text {th }}$ century BC. Photo: (C) Museum of Cultural History, University of Oslo, inv. C41798.

In 1883, when the German version of his famous dissertation on The Beginning of the Iron Age in Northern Europe had just appeared, Ingvald Undset visited Athens. Heinrich Schliemann (who seems to have judged books by quotability, and found much to quote in Undset's work) received him with open arms, and for weeks he was a regular visitor in the Schliemann household, on which he has shrewd observations in his travel memoirs. 'The collection rooms in Schliemann's home', he writes, 'contain mostly finds from his most recent Troy excavation ... Besides, from the Classical age in Greece, he has vases and bronzes, acquired mostly by purchase'. ${ }^{18}$

Where there is no indication to the contrary, the items had presumably been picked up in the Athenian art market. Among them are three truly remarkable Corinthian objects; they have been published before, but must not be passed over in an assessment of the royal gift. Corinthian amphoriskoi are usually a rather sorry sight, decorated carelessly with rows of animals. The example in the collection (Fig. 11a-b, C41798) is one of very few imperfections - shape fuller and more resilient, decoration unusual in kind and vigorously drawn with much interesting detail. ${ }^{19}$ The vase has amused and instructed generations of students. By comparing it to representations of a similar sort, e.g. the easternmost parts of the Parthenon Frieze, it is evident that the girls carrying sacrificial gear must form the head of the procession, whatever the old accessions list says. The girls are small, partly because they are young, partly to leave room for their burden. Each tray has sacrificial jugs at the ends; on the foremost there is an addition of a square box, on the last of the three, there are black dots that may stand for grain. After the tray-carriers there is the victim, with the knotted sacrificial ribbon on his horns, and he trots willingly along without need for an attendant: this was considered the best possible omen. Next, is the person who offers

\footnotetext{
18 Undset 1892, 99.

19 Amyx 1988, 497, 658; CV A Norway 1, 17, pl. 4.1-3.
} 

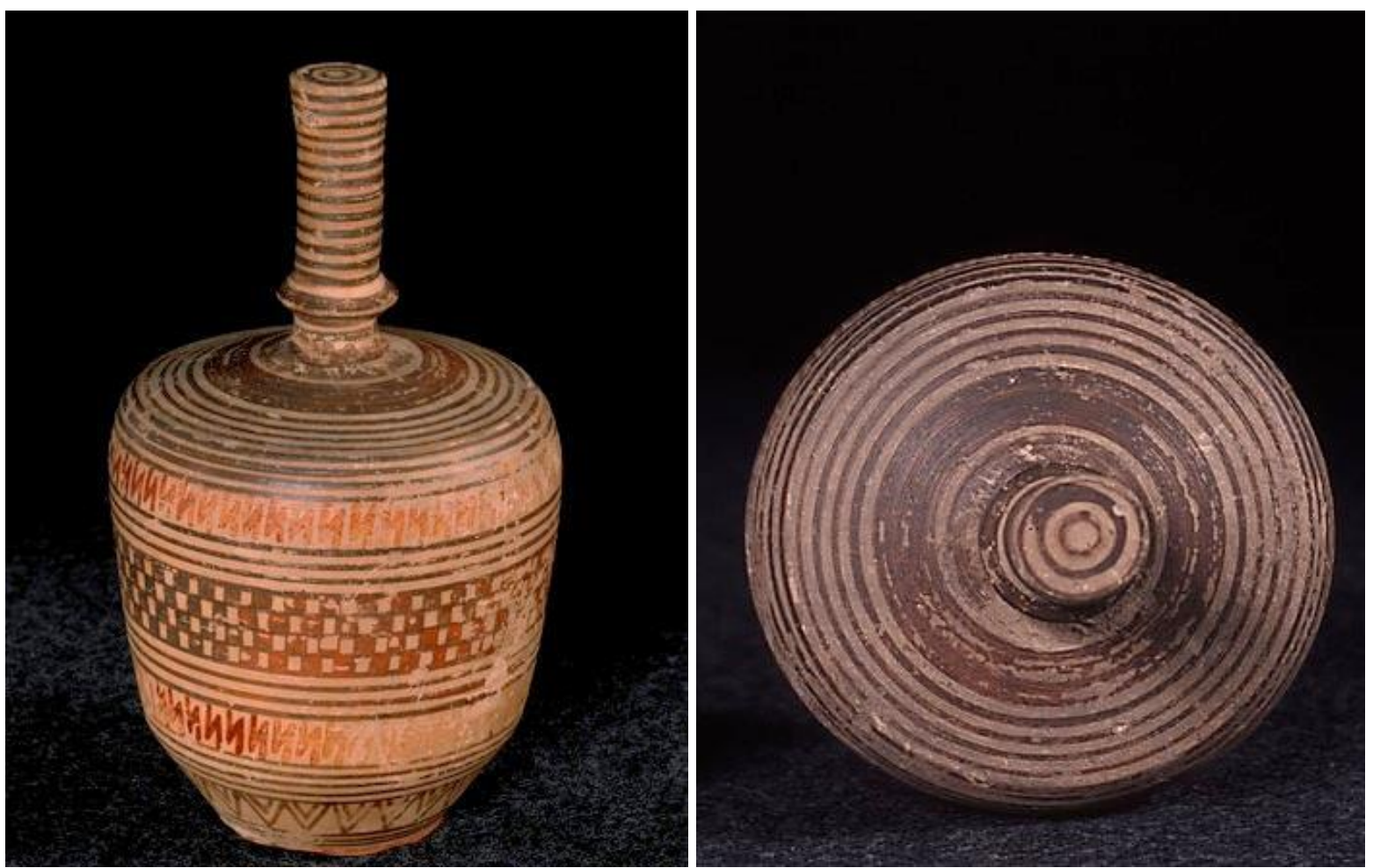

Fig. 12a-b V ase without opening. From Corinth, $7^{\text {th }}$ century BC.

Photo: (C) Museum of Cultural History, University of Oslo, inv. no. C41799.

the sacrifice, or officiates, or - most probably - combines both functions. He and the bull seem to be the only males present; the musician is female, as are the two figures who make up the procession. The painter was a master of the craft, and could deserve one of those made-up names by which decorators are known to archaeologists - 'Oslo Painter' would be apt, and has in fact been used at a time when it was thought that other works by the same hand could be identified. ${ }^{20}$ 'Names' are not usually given to authors of singletons.

The attributions resulted from the confusion of 'style' (a painter's individual handwriting) with 'manner', a convention shared by several painters. Our painter's style appears in the fluent drawing of the bull; the human figures have some elegance, but the rendering is deliberately primitive, stiff and angular with sparing use of incision for details, much of it along the contours. The manner is peculiar to scenes of cult - sometimes with children, always with women - with chains of female dancers, and is known as Franenfest. ${ }^{21}$ The hieratic air must be due, surely, to imitation of venerable models. What they were, one can only speculate: there were wall-paintings in Corinthian sanctuaries, but when the amphoriskos was decorated they were too new to seem old-fashioned, as far as we can tell. ${ }^{22}$

The ultimate source of the Framenfest convention may be of the same period - the earlier seventh-century - as the two vases 'without opening', C41799 and C41803, though they have only abstract ornaments in the Geometric tradition (Fig. 12a-b, C41799 and Fig. 13a-b, C41803). They are votive models of poppy-heads, as features derived from nature demonstrate. ${ }^{23}$ The raised ridge with many indentations of $\mathrm{C} 41803$ renders the division into seed-chambers on the real poppy; the ring near the top of the stalk, on C41799, shows from where the petals issued. The poppy is associated with the goddesses Demeter and Persephone (Kore); the former found

\footnotetext{
20 Amyx 1988, 658; CVA Norway 1, loc. cit.

${ }^{21}$ Amyx 1988, 653-657; Jucker 1963.

22 Broneer 1971, 33-34.

${ }^{23}$ CV A Norway 1, 13, pl. 1.2-3 (C41803 only); Seeberg 1969, 7-8, pl. 1a-b.
} 

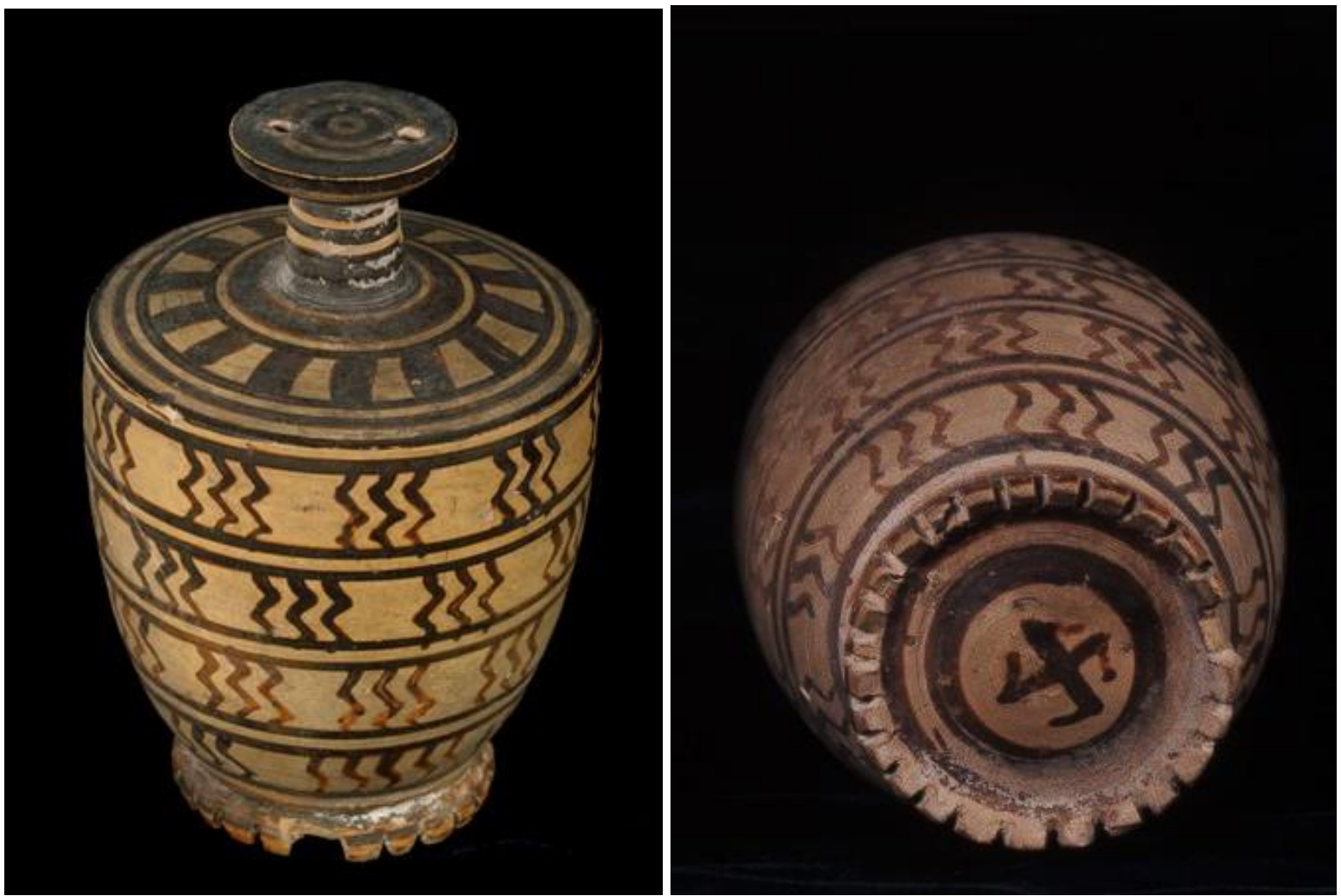

Fig. 13a-b V ase without opening. From Corinth, $7^{\text {th }}$ century BC. Photo: (C) Museum of Cultural History, University of Oslo, inv. no. C41803.

solace in eating poppy-seeds while searching for her lost daughter. The pomegranate is another fruit with such associations, and pomegranate-models are common, but poppy-heads are rare.

There are such objects in the Museum of Argos, of local make that remain unpublished. Of specimens decorated in Corinthian style, there seem to be only two in existence in addition to those in Oslo - one in Athens, from Perachora near Corinth, the other from Syracuse. ${ }^{24}$ Both are fragmentary. They are hollow; vases without an opening will burst if fired in the normal way, but they survive if heated slowly so that gases can escape through the porous wall. ${ }^{25}$ This implies individual treatment in the process of manufacturing, which would make such models of fruits relatively costly. As both are in perfect condition and come from one collection, there may be a certain presumption that they were found together (in a grave?), but they are an oddly matched pair. They may be of one age, but if so, hardly from one workshop.

During his stay in Athens, Ingvald Undset unexpectedly met a friend, Professor Hampel from Budapest, ${ }^{26}$ who had been commissioned by a Hungarian collector to purchase antiquities, Tanagra figures in particular. Undset had little to spend, but came along to the dealers more or less for the fun of it; the two pooled their expertise and were not to be fooled by forgeries. Genuine attractive pieces were offered at horrendous prices and on promise of discretion. In a shop off Hermes Street, Hampel finally found what he wanted. With much humour, his friend describes the bartering, with endless small-talk and innumerable cigarettes, until the bargain was struck - with, by way of balance, 'a less excellent, but whole and decent figure', which Undset received for the twenty francs that it cost. ${ }^{27}$

\footnotetext{
${ }^{24}$ Orsi 1918, 353-754 (from the site of the Athena Temple, Syracuse); Payne 1940, 94, pl. 25.1-2.

${ }^{25}$ Noble 1965, note 13 and 24; Shefton 1970, 61; Vickers 1970, 200.

${ }^{26}$ József Hampel (1849-1913), archaeologist, is considered to have been one of the founders of modern archaeological scholarship in Hungary.

${ }^{27}$ Undset 1892, 129-130.
} 
That is certainly the one that is included in the list of the Ethnographical Museum, where it appeared to have been overlooked at first, then squeezed in as an afterthought (mentioned above, Fig. 2, C41776). It is a seated youth - not a woman, as strangely maintained in the list bareheaded, wearing a wide cloak, with a square venthole in the seat at the back. It measures 130 $\mathrm{mm}$ in height, $60 \mathrm{~mm}$ in width, and $40 \mathrm{~mm}$ in depth from front to back. There are traces of pink on the seat, and of brown on the hair. It is unremarkable, as Undset observed, but has a good authentic air.

If it entered the museum at the same time as the royal donation, it was part of the transaction that transformed the antique collection of Oslo University from next to nothing into a small jewel and a nest-egg for future growth. We shall never know why the delivery took four years - if it did - but will forever remember the three names concerned: Schliemann, Undset, and Oscar II.

Axel Seeberg (†)

Institute of Archaeology, Art History and Conservation

University of Oslo

J. Rasmus Brandt

The Norwegian Institute in Rome

University of Oslo

j.r.brandt@iakh.uio.no 


\section{Bibliography}

\section{Abbreviation}

CVA Corpus Vasorum Antiquorum.

Amyx, D. A. 1988: Corinthian vase-painting of the Archaic period: Catalogue V 1 (California studies in the history of art 25). Berkeley: University of California Press.

Broneer, O. (ed.) 1971: The temple of Poseidon (Isthmia 1). Princeton: American School of Classical Studies at Athens.

Eriksen, A. 2009: Museum: en kulturhistorie. Oslo: Pax.

Hegard, T. 1984: Romantike og fortidsvern. Historien om de forste friluftsmuseene $i$ Norge. Oslo: Universitetsforlaget.

Hofstetter, E. 1990: Sirenen im archaischen und klassischen Griechenland. Würzburg: Konrad Triltsch Verlag.

Jucker, I. 1973: 'Frauenfest in Korinth', Antike Kunst 6: 43-61.

Kourou, N. 2007: 'Silent offerings and dutiful parents: Amphoriskoi and multiple vases in Early Iron Age child

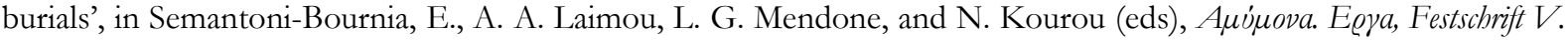

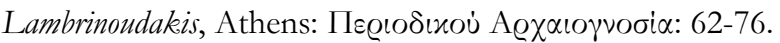

Nielsen, Y. 1907: Universitetets ethnografiske samlinger 1857-1907: en historisk oversigt over deres tilblivelse, vaekst og udvikling. Christiania: W. C. Fabritius and Sons.

Nielsen, Y. 1913: Fra Johan Sverdrups dage. Oplevelser og nedtegnelser 1884-1889. Christiania: Gyldendal.

Noble, J. V. 1965: The techniques of painted Attic pottery. New York: Watson-Guptill Publications and The Metropolitan Museum of Art.

Orsi, P. 1918: 'Gli scavi intorno a l’Athenaion di Siracusa: negli anni 1912-1917’, Monumenti antichi 25: 353-762.

Payne, H. (ed.) 1940: Perachora I. The sanctuaries of Hera Akraia and Limenia: excavations of the British School of Archaeology at Athens 1930-1933. Oxford: Clarendon Press.

Schliemann, H. 1958: Briefwechsel. Aus dem Nachlass in Auswabl herausgegeben von Ernst Meyer. II. Band. Von 1876 bis 1890. Berlin: Verlag Gebr. Mann.

Seeberg, A. 1953: ‘A Corinthian aryballos in Oslo’, Symbolae Osloenses 30: 92-99.

Seeberg A. and S. Marstrander 1964: Corpus Vasorum Antiquorum: Norway. Public and private collections: fascicule 1. Oslo: Universitetsforlaget.

Seeberg, A. 1969: 'Poppies, not pomegranates', Acta ad archaeologiam et artium bistoriam pertinentia 4: 7-12.

Seeberg, A. 1971: Corinthian komos vases (Bulletin supplement 27). London: University of London, Institute of Classical Studies.

Shefton, B. B. 1970: 'The Greek Museum, the University of Newcastle upon Tyne', Archaeological reports for 1969-70: $52-62$.

Skupinska-Løvset I. 2000: Corpus Vasorum Antiquorum: Norway. Public and private collections: fascicule 2. Oslo: University Museum of Cultural Heritage, The Antiquities Collection.

Sparkes, B. A. and L. Talcott 1970: The Athenian Agora 12. Black and plain pottery of the 6th, 5th and 4th centuries B.C. Princeton: American School of Classical Studies at Athens. 
Undset, I. 1892: Fra Akershus til Akropolis. Erindringer fra arkacologiske studiereiser. Christiania and Copenhagen: Alb. Cammermeyers forlag.

Vickers, M. 1970. 'A note on a rattling Attic black glaze cup in Dublin', Journal of Hellenic Studies 90: 199-201.

Wieseler, F. 1874: 'Archäologischer Bericht über seine Reise nach Griechenland', Abhandlungen der Königlichen Gesellschaft der Wissenschaften in Göttingen 19: 63-132.

Zippelius, A. 1974: Handbuch der europäischen Freilichtmuseen. Cologne: Rheinland-Verlag. 


\section{APPENDIX}

\section{Museum of Cultural History Inventory List: The First Acquisition}

C41069 Lamp from Athens, with Aktaion

C41786 Chalice from Locris, black-varnished, $4^{\text {th }}$ century (identified as alabastrotheke in the original list)

C41760 Three-handled vase (miniature bydria), from Athens, 'pre-Homeric' (Fig. 4)

C41761 Vase with two handles and open mouth, from Athens, 'pre-Homeric' (Fig. 3)

C41784 Rhyton from Attica with two heads and an inscription, $5^{\text {th }}$ century BC

C41785 Aryballos with Eros and a woman, from Athens, $3^{\text {rd }}$ century BC

C41788 Bell from Thebes, Boeotia (Fig. 10)

C41789 Two-handled vase in the shape of an almond, from Thebes (Fig. 9)

C41797 Athenian lekythos with two black sirens, $6^{\text {th }}$ century BC (Fig. 5)

C41798 Amphoriskos from Corinth with the representation of a sacrifice. A bull with a wreath goes first, then a priest followed by a fluteplayer; behind him 2 figures and 3 kanephoroi with sacrificial vessels, $6^{\text {th }}$ century BC (Figs 11a-b)

C41799 Vase without opening, from Corinth, $7^{\text {th }}$ century BC (Figs 12a-b) (dated to the $8^{\text {th }}$ century $\mathrm{BC}$ in the original list)

C41803 Vase without opening, from Corinth, a swastika on the lower surface, $7^{\text {th }}$ century BC (Figs 13a-b) (dated to the $8^{\text {th }}$ century BC in the original list)

C41804 Aryballos from Tanagra with 3 hoplites, $6^{\text {th }}$ century BC (Fig. 6)

C41806 Vase with lid, egg-shaped, from Corinth, $8^{\text {th }}$ century BC

C41814 Aryballos from Boeotia with 5 comic dancers, $6^{\text {th }}$ century BC (Fig. 8)

C42142 Aryballos with a boar, from Tanagra, $6^{\text {th }}$ century BC (Fig. 7)

C42197 Blue glass vessel, from Athens

C42714 Lekythos from Athens, with the representation of Polyphemos in the grotto with Odysseus under the ram, $6^{\text {th }}$ century BC

Later addition:

C41776 Tanagra figurine, seated young male (originally listed as female) 